\title{
MODEL-MODEL PEMBELAJARAN MEMBACA SEBAGAI INOVASI DALAM MENGEMBANGKAN BAHAN AJAR MEMBACA
}

\author{
Noermanzah \\ noermanzah@stkippgri-lubuklinggau.ac.id \\ Dosen STKIP PGRI Lubuklinggau
}

\begin{abstract}
Kemampuan membaca peserta didik sangat berpengaruh terhadap kemampuan berbahasa yang lain, terutama kemampuan berbicara dan menulis. Untuk itu, para pengajar dan peneliti selalu melakukan inovasi dalam meningkatkan kemampuan membaca peserta didik dengan cara memberikan model pembelajaran membaca yang menarik dan efektif. Walaupun pada kenyataannya pada setiap model pembelajaran membaca yang diterapkan memilikl kelebihan dan kekurangan. Hal ini, ditunjukkan dengan penggunaan model pembelajaran yang belum selaras dengan bahan ajar membaca yang dikembangkan. Belum lagi bahan ajar yang selalu berganti setiap waktu karena dipengaruhi beraneka ragam faktor. Faktor terjadinya perubahan penggunaan model bahan ajar membaca yang menjadi perhatian utama para pelaku pendidikan yaitu dikarenakan perubahan kurikulum dan perubahan pengembangan bahan ajar membaca yang digunakan. Penulisan makalah ini bertujuan untuk menjelaskan beberapa model pembelajaran membaca yang digunakan oleh pengajar bahasa Indonesia yang dapat digunakan juga dalam mengembangkan bahan ajar membaca. Metode penulisan dalam makalah ini menggunakan metode studi pustaka atau studi literatur. Teknik pengumpulan data mengggunakan teknik dokumentasi. Teknik analisis data dalam penulisan makalah ini dengan langkah-langkah, yaitu reduksi, analogi, sintesis, interpretasi, dan kesimpulan. Hasil penulisan makalah ini yaitu beberapa model pembelajaran membaca yang dapat digunakan dalam menerapkan bahan ajar membaca yang dikembangkan, yaitu: model Anticipation Guide, model Model DRTA, Model SQ3R, model ECOLA, model Jigsaw Learning, model Index Card Match, model Card Sort, model OH-RATS, Model Directed Inquiry Activity, model KWLA, model pembelajaran ARIAS, model PORPE, model membaca berdasarkan pola berpikir, model pembelajaran berbasis genre, dan Model CLIL.
\end{abstract}

Kata kunci: model pembelajaran membaca, inovasi, pengembangan, bahan ajar membaca.

\section{Pendahuluan}

Membaca memiliki peran utama, tidak hanya untuk pembelajaran bahasa Indonesia sendiri, tetapi juga untuk keperluan pembelajaran bidang-bidang studi lainnya, karena hampir seluruh pengetahuan pada masing-masing bidang studi disajikan dalam bentuk tertulis (Ngalimun \& Alfulaila, 2014: 34). Dengan membaca, siswa akan memperoleh dan menguasai pengetahuan dan keterampilan yang bermanfaat bagi pertumbuhan dan perkembangan daya nalar, sosial, dan kreasinya serta dapat bermanfaat untuk mencapai tujuan belajar yang diinginkannya.

Membaca juga akan mendekatkan siswa dengan ilmu pengetahuan, teknologi, kebudayaan, seni, dan yang 
berhubungan dengan perkembangan informasi. Harvey\& Goudvis (2013:432439) menjelaskan bahwa dalam mencapai dan memenuhi persaingan dan tantangan global yang semakin kompleks, diperlukan strategi pemahaman bacaan sehingga siswa mampu mengubah informasi menjadi pengetahuan dan secara aktif dapat digunakan.

Kemampuan membaca siswa di Indonesia masih tergolong rendah dibandingkan dengan negara-negara lain. Hal ini dibuktikan dengan hasil dari penelitian Progress in International Reading Literacy Study (PIRLS) pada tahun 2011 yang menunjukkan bahwa kemampuan membaca siswa sekolah dasar di Indonesia berada pada posisi ke42 dari 45 negara (Mullis, Nartin, Foy, \& Drucker, 2012). Hal ini memberikan informasi bahwa kemampuan membaca siswa di Indonesia masih tergolong dalam kategori rendah.

\begin{tabular}{llll}
\multicolumn{2}{c}{ Kemudian, } & menurut & hasi \\
penelitian yang & dilakukan & oleh \\
Universitas Negeri & Conneticut & Pusat
\end{tabular} Amerika Serikat (CCSU) (dalam Mohamad, 2016), menyusun pemeringkatan kemampuan baca dengan jumlah yang lebih dari 60 negara. Yang mengejutkan bahwa hasilnya, negara Indonesia berada di urutan ke-60, setingkat di atas Bostwana, dan masih di bawah Thailand pada urutan 59 atau Maroko pada urutan 58. Beberapa informasi ini menunjukkan bahwa siswa di Indonesia masih mengalami kesulitan dalammemahami bacaan dalam teks.

Para pengajar, baik guru maupun dosen dalam pelaksanaan pembelajaran membaca seringkali dihadapkan pada peserta didik yang mengalami kesulitan belajar membaca khususnya di kelas rendah. Peran guru sebagai fasilitator sangat berpengaruh besar terhadap perkembangan peningkatan belajar anak. Keberhasilan belajar anak tidak lepas dari cara guru membimbing dan mendidik siswanya. Selain itu, guru harus mempertimbangkan pemenuhi kebutuhan indera belajar siswa. Artinya, pembelajaran yang dilaksanakan guru bersama siswa harus bisa memenuhi kebutuhan siswa yang dominan baik di visual, auditorial, maupun kinestetik. Selain itu, guru bahasa Indonesia harus berperan menciptakan pembelajaran yang kreatif dan berpikir kritis (Noermanzah, 2015:274).

Salah satu cara dalam meningkatkan kemampuan membaca siswa yaitu memberikan langkah-langkah pembelajaran dalam kegiatan membaca dengan menggunakan model pembelajaran yang tepat sesuai dengan bahan ajar yang digunakan oleh pengajar. Model pembelajaran membaca yang akan dijelaskan dalam makalah ini yaitu modelAnticipation Guide, model DRTA (Directed Reading-Thinking Activity), Model SQ3R (Survey, Question, Read, Recite, Review), model ECOLA (Extending Concept throught Language Activities), model Jigsaw Learning (Belajar Model Jigsaw), model Index Card Match (Mencari Pasangan), model Card Sort (Kartu Sortir), model OH RATS (Overview, Headings, Read, Answer, Test-Study), model Model Directed Inquiry Activity, model KWLA (What I Already Know, What I Want to Know, What I Learned, and The Affect of the Story), model Pembelajaran ARIAS (Assurance, Relevance, Interest, Assesment, Satisfaction), Model PORPE(Predict. Organize, Rehearse, 
Practice, and Evaluate), Model membaca berdasarkan pola berpikir, model pembelajaran berbasis genre, dan Model Content and Language Integrated Learning (CLIL).

Diharapkan dengan menjelaskan beberapa model pembelajaran membaca di atas, mampu menjadi referensi pengajar bahasa Indonesia dalam menggunakan model pembelajaran membaca dan harapannya mampu meningkatkan kemampuan membaca siswa. Selain itu, dalam menggunakan model pembelajaran membaca juga bukan hanya bisa diterapkan dalam pembelajaran bahasa Indonesia juga dapat diterapkan pada beberapa mata pelajaran lain yang memiliki karakter yang sama.

\section{METODE PENELITIAN}

Dalam makalah ini menggunakan metode studi pustaka atau studi literatur, yang dibantu dengan analisis isi. Data dalam makalah ini yaitu informasi yang berkaitan dengan modelmodel pembelajaran membaca. Teknik pengumpulan data mengggunakan teknik dokumentasi yang diperoleh dari buku, jurnal, dan prosiding. Teknik analisis data dalam penulisan makalah ini dengan langkah-langkah, yaitu reduksi, analogi, sintesis, interpretasi, dan kesimpulan.Uji keabsahan data dalam makalah ini menggunakan teknik triangulasi dari beberapa sumber referensi.

\section{HASIL DAN PEMBAHASAN}

Model pembelajaran membaca sudah banyak diterapkan oleh para pengajar khususnya pengajar bahasa
Indonesia. Beberapa model pembelajaran tersebut dikolaborasikan ke dalam bahan ajar membaca sehingga mampu benar-benar meningkatkan kemampuan membaca. Beberapa model pembelajaran membaca yang dapat meningkatkan kemampuan membaca siswa, sebagai berikut.

\section{Model Anticipation Guide}

Model Anticipation Guide juga
masuk dalam strategi dalam meningkatkan kemampuan membaca pemahaman yang dikembangkan oleh pakar pengajaran bahasa yiatu Erickson, Bean, Hubler, Smith, dan McKenzie pada tahun 1987. Model Anticipation Guide dijelaskan oleh Tierney, dkk. (1990:38) sebagai salah satu model pembelajaran yang bermanfaat untuk membantu siswa dalam berpikir kritis. Model pembelajaran ini dilaksanakan dengan cara meminta siswa untuk bereaksi terhadap beberapa pernyataan yang berkaitan dengan isi materi teks. Reaksi yang muncul dapat berupa prediksi atau perkiraan mengenai isi materi yang akan dibaca. Model Anticipation Guide bertujuan agar siswa mampu menstimulasi suatu informasi dan mengantisipasinya sehingga siswa mampu memberikan respons kritis terhadap beberapa pernyataan yang terdapat dalam bacaan tersebut. Model pembelajaran ini juga mampu membiasakan siswa untuk terampil berbicara melalui kegiatan diskusi ketika memprediksi suatu isi bacaan.

Kemudian, menurut Wiesendanger (2001:78), model Anticipation Guide berfungsi untuk meningkatkan kemampuan berpikir kritis dengan cara mempersiapkan siswa untuk membaca, kemudian meminta mereka untuk 
bereaksi terhadap beberapa pernyataan yang berkaitan dengan isi materi bacaan. Ketika bereaksi terhadap beberapa pernyataan, siswa mengantisipasi atau memperkirakan apa isi materi yang akan dibaca. Model Anticipation Guide terdiri atas sejumlah pernyataan deklaratif (informasi) yang dapat digunakan pada awal bagian teks. Guru memberi siswa sejumlah pernyataan dan meminta mereka, apakah mereka setuju atau tidak setuju dengan setiap pernyataan itu. Hal ini dilakukan agar siswa menyadari bahwa mereka benar-benar memproses informasi yang akan membantu mereka untuk memahami materi bacaan dengan lebih baik. Teknik ini memungkinkan siswa untuk menghubungkan apa yang mereka sudah ketahui dengan informasi baru yang terdapat dalam teks.

Model Anticipation Guide dapat meningkatkan pemahaman siswa dengan meminta mereka bereaksi terhadap pernyataan tentang topik sebelum mereka membaca teks. Hal ini mengaktifkan pengetahuan sebelumnya sebagai perangkat motivasi agar siswa terlibat dalam pemahaman materi teks yang akan dibaca. Model ini juga dapat digunakan dengan baik dalam membaca teks eksposisi dan narasi, dan dapat diterapkan untuk setiap tingkat kelas. Wiesendanger (2001) menjelaskan beberapa langkah dalam menerapkan model Anticipation Guide, sebagai berikut:

a. Membaca materi dan mengidentifikasi konsep utama.

b. Mengantisipasi pengetahuan sebelumnya pada peserta didik terhadap topik yang disajikan.

c. Mempertimbangkan konsep-konsep penting, menuliskan sedikitnya 3 sampai 10 pernyataan luas. Pernyataan yang paling efektif adalah pernyataan yang berisi informasi dengan latar belakang pengetahuan siswa yang cukup.

d. Menyajikan pernyataan kepada siswa dalam urutan kronologis yang sama seperti yang akan ditemukan siswa dalam bahan bacaan.

e. Menempatkan panduan pada papan tulis, OHP/LCD, atau handout sehingga mudah dibaca oleh seluruh kelas. Membaca petunjuk itu dengan suara keras kepada siswa.

f. Dalam kelas, membahas setiap pernyataan secara singkat dan tanyakan kepada siswa apakah setuju atau tidak setuju dengan setiap pernyataan yang diberikan. Kemudian, mendorong siswa untuk mengevaluasi jawaban mereka dan mendengarkan pendapat dari rekanrekan mereka.

g. Setelah membahas pernyataan, mintalah siswa membaca teks. Setelah pembacaan selesai, mintalah siswa untuk merespon sekali lagi terhadap pernyataan-pernyataan itu. Kemudian, meminta respons siswa yang berbeda dengan yang sebelumnya karena sekarang pemahaman mereka didasarkan pada teks yang telah dibaca. Jika siswa tidak setuju dengan penulis, mintalah siswa untuk mendukung kesimpulan mereka berdasarkan informasi dalam teks. Fokuskan kegiatan akhir pembelajaran ini pada perbandingan pernyataan dalam panduan sebelumnya dan setelah membaca materi.

2. Model DRTA (Directed ReadingThinking Activity) 
Model DRTA (Directed ReadingThinking Activity) dikembangkan oleh Stauffer tahun 1996. DRTA adalah teknik yang memandu siswa melalui membaca, membuat prediksi, membaca ulang, dan mengkonfirmasikan atau menyesuaikan kembali prediksi. Model ini membantu siswa dalam pengembangan pemahaman bacaan (teks narasi) dan kemampuan berpikir kritis (Wiesendanger, 2001). Model ini melibatkan para siswa dalam memprediksi apa isi cerita yang dipikirkan mereka. Model DRTA ini berupa kegiatan dalam siklus yang meliputi: memprediksi, membaca, dan membuktikan karena kegiatan membaca adalah kegiatan berpikir, yang melibatkan pembaca menggunakan pengalaman sendiri untuk merekonstruksi ide-ide penulis.

Kemudian, menurut Kubowitz (2012:202), model DRTA merupakan cara yang memadukan peserta didik dengan langkah-langkah yaitu membaca, membuat prediksi, membaca ulang, dan membuktikan atau mengkonfirmasikan kembali prediksi yang telah disusun. Model DRTA ini melibatkan para peserta didik dalam memprediksi apa isi cerita yang dipikirkan mereka sehingga mampu merekonstruksi ide-ide yang disampaikan penulis dalam bacaan. Model ini dapat digunakan pada setiap tingkat pembaca, bisa dalam kelompok atau individu dan biasanya dalam bentuk wacana narasi dan eksposisi.

Beberapa langkah pembelajaran dengan menggunakan model DRTA, sebagai berikut.

a. Berikanlah setiap peserta didik salinan bacaan yang telah dipilih. Mintalah peserta didik untuk mempelajari judul dan gambar pada halaman pertama. Ajukan pertanyaan seperti berikut: Apa yang kamu pikirkan tentang cerita dengan judul ini?Apa yang kamu pikirkan tentang peristiwa dalam cerita ini?Manakah prediksimu yang sesuai?

b. Ketika pertama kali memperkenalkan Directed ReadingThinking Activity, biasakan siswa dengan strategi untuk menangani dengan kata-kata yang belum dikenal: baca akhir kalimat, gunakan gambar jika tersedia, ucapkan katakata dengan suara nyaring, dan mintalah bantuan orang lain.

c. Mengarahkan siswa untuk membaca dalam hati bagian dari cerita untuk memeriksa prediksi mereka. Pastikan bahwa siswa membaca untuk mencari makna. Amati kinerja membaca mereka dan bantu siswa yang membutuhkan bantuan dengan kata-kata yang mungkin sulit dipahami.

d. Setelah siswa telah membaca bagian pertama, minta mereka menutup buku mereka. Apakah pertanyaanpertanyaan berikut memandu siswa untuk mengevaluasi temuan dan prediksi baru mereka: apakah Anda benar, apa yang Anda pikirkan sekarang, dan menurut Anda apa yang akan terjadi? Kemudian, doronglah siswa untuk menyaring beberapa ide mereka dan untuk membuat prediksi tentang peristiwa yang akan terjadi kemudian dalam bacaan.

e. Mintalah siswa melanjutkan kegiatan membaca bagian lain. Pada setiap bagian bacaan, lanjutkan siklus memprediksi-membaca- 
membuktikan 2001).

3. Model SQ3R (Survey, Question, Read, Recite, Review)

Model SQ3R (Survey, Question, Read, Recite, and Review) adalah strategi yang dikembangkan oleh Adams, Carnine, \& Gersten tahun 1982; Mangrum \& Strichart tahun 1996; Scott tahun 1994; dan Stahl, King dan Eilers, tahun 1996. Model ini meliputi kegiatan memprediksi dan mengelaborasi yang digunakan untuk meningkatkan pemahaman literal dan membantu dalam pembentukan keterampilanh belajar (Wiesendanger, 2001). SQ3R adalah strategi yang memperkenalkan pengorganisasian, prediksi, dan pemahaman. Siswa mensurvei, bertanya, membaca, merenungkan, dan meninjau kembali materi teks yang dibaca. Strategi ini dapat meningkatkan pemahaman siswa terhadap informasi tertulis dan membantu mereka menyimpan informasi untuk bahan diskusi, kuis, dan tes.

Pembelajaran Survey, Question, Read, Recite, and Review sangat terstruktur dan membantu pengingatan materi serta dapat digunakan untuk kelas 5-12, baik dengan teks narasi maupun ekspositori. Langkah-langkah pembelajaran dengan menggunakan model SQ3R, sebagai berikut:

a. Survey, dengan cara memintapeserta didik untuk melakukan hal berikut: (a) membaca judul dan memikirkan maknanya; (b) membaca bagian pendahuluan yang biasanya ditemukan di paragraf pertama atau kedua; (c) membaca bagian teks di sebelah subbab untuk mempelajari apa isi teks tersebut; (d) memeriksa semua gambar yang ada dan membaca keterangan yang ada; serta (e) membaca kesimpulan yang biasanya ditemukan di paragraf terakhir atau kedua.

b. Question, dengan cara meminta peserta didik untuk melakukan hal berikut: (a) mengubah judul menjadi satu atau dua pertanyaan. Gunakan kata kunci untuk melengkapi pertanyaan: siapa, apa, di mana, kapan, mengapa, dan bagaimana; (b) ubahlah subbab dalam satu atau dua pertanyaan. Gunakan kata kunci untuk melengkapi pertanyaan: siapa, apa, di mana, kapan, mengapa, bagaimana; dan (c) tulislah pertanyaan tersebut.

c. Read, dengan cara meminta peserta didik untuk melakukan hal berikut: a) membaca untuk menjawab pertanyaan; b) mengubah pertanyaan yang diperlukan untuk menjawab pertanyaan penulis; dan c) menulis jawaban dari pertanyaan untuk melengkapi catatan.

d. Recite, dengan cara meminta peserta didik untuk melakukan hal berikut: (a) membaca pertanyaan dan menjawab dengan suara keras; (b) membaca pertanyaan dengan keras; lalu palingkan muka dan katakan jawabannya dengan suara keras; (c) membaca pertanyaan dengan keras; lalu dengan mata tertutup katakan jawabannya dengan keras; dan (d) ulangilah.

e. Review, dengan melakukan hal yang sama seperti yang ada pada langkah 4 (Wiesendanger, 2001). 
4. Model ECOLA (Extending Concept throught Language Activities)

Model pembelajaran Extending Concept throught Language Activities (ECOLA) dikembangkan oleh Smith-Burke tahun 1982 dan bertujuan untuk mengintegrasikan membaca, menulis, berbicara, dan mendengarkan untuk pengembangan kemampuan keterampilan membaca. Model ini tepat digunakan untuk siswa tingkat menengah (SMP dan SMA/SMK) (Tierny, Readence, \& Dishner, 1995). Tahapan pelaksanaan ECOLA adalah sebagai berikut.

a. Menentukan tujuan yang komunikatif untuk membaca.

b. Membaca dalam hati.

c. Mewujudkan pemahaman peserta didik melalui aktivitas menulis dengan cara menuliskan tanggapan yang sesuai dengan tujuan yang diharapkan.

d. Diskusi dan klarifikasi pemaknaan.

e. Menulis hasil pemahaman dan membandingkan (Tierny, Readence, \& Dishner, 1995).

Selain dengan pendekatan dan strategi tersebut, pembelajaran membaca dapat dilakukan dengan berbagai teknik atau strategi, seperti strategi STUDY, PQRST, OK5R, EVOKER, dan sebagainya. Berbagai teknik tersebut dapat dilakukan secara bervariasi sehingga dapat mencegah kebosanan siswa dalam belajar membaca.

\section{Jigsaw Learning (Belajar Model Jigsaw)}

Model Jigsaw Learning merupakan model yang menarik untuk digunakan jika materi yang akan dipelajari dapat dibagi menjadi beberapa bagian dan materi tersebut tidak mengharuskan urutan penyampaian. Kelebihan model Jigsaw Learning adalah dapat melibatkan seluruh siswa dalam belajar dan sekaligus mengajarkannya kepada orang lain. Langkah-langkah pembelajaran dalam model ini adalah sebagai berikut.

a. Pilihlah materi pelajaran yang dapat dibagi menjadi beberapa bagian (segmen).

b. Bagilah peserta didik menjadi beberapa kelompok sesuai dengan jumlah segmen yang ada. Jika jumlah peserta didik adalah 50 sementara jumlah segmen ada 5 , maka masing-masing kelompok terdiri atas 10 orang. Jika jumlah ini dianggap terlalu besar, bagi lagi menjadi dua sehingga setiap kelompok terdiri dan 5 orang, kemudian setelah proses telah selesai gabungkan kedua kelompok pecahan tersebut.

c. Setiap kelompok mendapat tugas membaca dan memahami materi pelajaran yang berbeda-beda.

d. Setiap kelompok mengirimkan anggota-anggotanya ke kelompok lain untuk menyampaikan apa yang telah mereka pelajari di kelompok.

e. Kembalikan suasana kelas seperti semula kemudian tanyakan sekiranya ada persoalan yang tidak terpecahkan dalam kelompok.

f. Sampaikan beberapa pertanyaan kepada peserta didik untuk mengecek pemahaman mereka terhadap materi.

6. Index Card Match (Mencari
Pasangan)


Model ini digunakan pada keterampilan membaca dengan dengan memasangkan kartu-kartu. Peserta didik sebelumnya ditugaskan untuk membaca atau mempelajari topik tertentu. Langkah-langkah pembelajaran dalam model ini adalah sebagai berikut.
a. Guru membuka pembelajaran dengan menyampaikan tujuan/kompetensi pembelajaran.
b. Guru menentukan topik sesuai kompetensi dasar.
c. Siswa membaca teks bacaan yang telah disiapkan.
d. Guru menyiapkan kartu sebanyak jumlah siswa setengahnya pertanyaan dan setengahnya jawaban.

e. Siswa mendapat kartu secara acak dan setiap siswa mencari pasangan kartunya.

f. Setelah menemukan pasangannya siswa menjelaskan makna yang ada dalam kartu.

g. Guru dan siswa menyimpulkan pembelajaran.

h. Siswa merangkum materi dalam buku tugas.

\section{Card Sort (Kartu Sortir)}

Model Card Sortmerupakan bagian dari pembelajaran kooperatif yang mana siswa bergerak secara aktif dan dinamis mencari pasangan kartu. Langkahlangkah pembelajaran Card Sort, sebagai berikut.

a. Guru membuka pelajaran dengan menginformasikan tujuan/kompetensi pembelajaran.

b. Guru menyiapkan kartu sebanyak siswa sesuai kategori. c. Guru meminta siswa mempelajari teks bacaan yang berkaitan KD ensiklopedia.

d. Guru membagikan kartu kepada siswa dan siswa mencari kelompok dengan kategori yang sama.

e. Siswa yang sudah berkumpul dengan kelompoknya masing-masing diminta mendiskusikan dan menempel kartu pada kertas.

f. Siswa memajang dan mempresentasikan hasil kelompoknya sedangkan kelompok lain dapat memberikan komentar.

g. Guru dan siswa menyimpulkan pembelajaran.

h. Siswa merangkum materi dalam buku tugas.

8. Model OH-RATS (Overview, Headings, Read, Answer, Test-Study)

$$
\text { Model OH-RATS yang }
$$

dikembangkan oleh Berrent tahun 1984 ini mencakup kegiatan membaca, memilih informasi yang relevan, dan mereview. Model OH-RATS ini terdiri dari overview, headings, read, answer, dan test-study. Strategi ini bukan metode untuk menulis catatan, tetapi strategi ini cocok untuk siswa yang belajar menulis catatan berdasarkan pada apa yang dibaca (Wiesendanger, 2001). Langkah pembelajaran dalam model OH-RATS, sebagai berikut.

a. Tahap Overview. Dalam rangka mengembangkan tahap overview untuk membaca, peserta didik diharuskan menentukan tipe teks yang akan muncul kemudian. Pertama, mintalah peserta didik untuk melihat judul bab dan subbab untuk mengembangkan apa yang mereka diharapkan. Mintalah peserta didik 
untuk menentukan jika ada pengantar dan ringkasan pada bagian itu. Pada tahap ini, mintalah peserta didik membuat pertanyaan yang mungkin dapat terjawab dalam teks yang akan dibaca nanti.

b. Tahap Headings. Mintalah peserta didik untuk mengunakan buku catatan hanya untuk satu tujuan. Pada bagian awal setiap halaman tersendiri, mintalah peserta didik untuk menulis jdul dan nomor halaman dan melipat tiap-tiap kertas. Pada bagian kiri, peserta didik diminta menulis beberapa pertanyaan untuk setiap judul atau subjudul.

c. Tahap Read. Mintalah peserta didik untuk membaca teks secara keseluruhan dengan teknik membaca dalam hati. Jangan biarkan peserta didik membaca terlalu panjang pada suatu bagian teks. Bagilah teks itu menjadi beberapa bagian sehingga memudahkanpeserta didik. Guru dapat menentukan batasan judul atau subjudul sebagai bahan yang dibaca peserta didik.

d. Tahap Answer. Mintalah peserta didik untuk menentukan informasi yang tepat dan tempatkan di kolom kanan dari halaman lipat. Ingatkan peserta didik bahwa hal ini haruslah berisi pokok-pokok penting dan mintalah peserta didik melengkapinya untuk setiap bagian teks.

e. Tahap Test Study. Mintalah peserta didik untuk mengunakan catatan yang mereka buat untuk melengkapi review akhir mereja. Dengan catatan mereka pada halaman yang dilipat setengahnya, mintalah peserta didik membaca pertanyaan pada setia bagian dan mencoba untuk menjawab tanpa melihat teks yang ada di sebelah kanan. Mintalah peserta didik untuk menggunakan catatan hanya jika dibutuhkan (Wiesendanger, 2001).

\section{Model Directed Inquiry Activity}

Model Directed Inquiry Activity dikembangkan oleh Lehr tahun 1980 dan Thomas tahun 1978. Model ini membantu meningkatkan pemahaman pembaca di dalam pembelajaran membaca berbagai bidang studi. Model ini membantu siswa dalam memilih informasi penting dan mengkategorikan informasi tersebut khususnya dalam informasi dari buku teks mata pelajaran (Wiesendanger, 2001). Strategi ini membantu siswa dalam mengatur, mengolah, dan memahami materi teks yang ditugaskan.

Penggunaan enam pertanyaan membantu siswa dalam memahami teks baik teks narasi maupun teks ekspositori. Langkah-langkah yang digunakan dalam modelDirected Inquiry Activity, sebagai berikut.

a. Mintalah siswa melihat-lihat bagian teks yang ditugaskan.

b. Ajukan enam pertanyaan, yakni siapa, apa, kapan, di mana, mengapa, dan bagaimana.

c. Catat prediksi peserta didik di papan tulis dengan kategori yang sesuai. Gunakan pertanyaan pemeriksaan dan teknik elaborasi agar siswa dapat mengingat informasi penting yang berkaitan dengan teks.

d. Mintalah siswa membaca teks secara keseluruhan dan buatlah beberapa perubahan yang diperlukan untuk prediksi mereka. 
e. Gunakanlah grafik pramembaca untuk memodifikasi strategi yang digunakan sebagai strategi pra membaca dan pasca membaca (Wiesendanger, 2001).

10. Model KWLA (What I Already Know, What I Want to Know, What I Learned, and The Affect of the Story)

Model KWLA (What I Already Know, What I Want to Know, What I Learned, and The Affect of the Story) dikembangkan oleh Carr and Ogle tahun 1987, serta Mandeville tahun 1994. Model ini tidak hanya membantu siswa untuk menghubungan apa yang mereka ketahui, tetapi juga memungkinkan siswa untuk menilai sendiri kesesuaian, ketertarikan, dan nilai personal terhadap pengalaman belajar mereka. Model ini mefokuskan pada elaborasi dan pemantauan pemahaman siswa. Model ini bisa digunakan pada saat sebelum membaca, saat membaca, atau fase akhir membaca.

Model KWLA dapat digunakan dalam pembelajaran membaca teks naratif atau ekspositorif. Strategi ini cocok untuk siswa dalam semua kemampuan dari SD sampai SMA (Wiesendanger, 2001). Langkah-langkah model pembelajarn KWLA, sebagai berikut.

a. Membuat tabel dengan empat kolom.

b. Bertanya kepada peserta didik apa yang telah mereka ketahui untuk tentang topik yang akan dibaca. Tulislah informasi itu pada kolom pertama.

c. Bertanya kepada peserta didik pertanyaan apa yang akan mereka jawab tentang topik yang akan dibaca. Tulis pertanyaan ini dalam kolom dua.

d. Setelah membaca, mintalah peserta didik untuk menjawab pertanyaan dan informasi lainnya dalam kolom tiga.

e. Gunakan kolom empat untuk menulis jawaban pertanyaan pertama yang berpengaruh. Salah satu contoh pertanyaan: apa yang membuat saya tertarik. Siswa secara reflek memiliki informasi penting oleh jawaban dalam pertanyaan: mengapa informasi ini penting untuk saya dan bagaimana membantu saya mengetahui informasi tersebut.

f. Jelaskan kepada peserta didik jika mereka juga dapat menggunakan kolom ke empat untuk merespon dengan sikap yang baru tentang pembelajaran mereka. Contohnya peserta didik mungkin mencatat tentang jangkrik dan serangga lainnya mendapatkan tempat yang baik dalam budaya Asia

g. Kemudian kegiatan diskusi. Jika guru meminta peserta didik untuk mendengarkan respons teman sebayanya, dan berbicara tentang respon sendiri, dan kemudian respon tertulis mereka kualitasnya akan lebih baik (Wiesendanger, 2001).

11. Model Pembelajaran ARIAS (Assurance,

Relevance, Interest, Assesment, Satisfaction) Dalam kaitan pembelajaran membaca, siswa saat melakukan aktivitas membaca akan berusaha secara maksimal memahami isi teks bacaan. Dalam memahami bacaan tentunya 
siswa membutuhkan proses yang membuat dirinya termotivasi untuk membaca model ARIAS ini sangat membantu siswa dalam memotivasi siswa dalam melakukan kegiatan membaca. Beberapa langkah model pembelajaran ARIAS, sebagai berikut:

a. Assurance, siswa diberikan rasa kepercayaan diri oleh guru tentang kemampuan siswa dalam memahami bacaan.

b. Relevance, guru menghubungkan isi bacaan dengan pengalaman siswa.

c. Interest, guru mengarahkan minat dan perhatian siswa terhadap sesuatu yang dipelajarinya.

d. Assesment, guru memberikan penghargaan kepada siswa terhadap hasil evaluasi atau penilaian terhadap perkembangan belajar siswa dalam menentukan isi bacaan.

e. Satisfaction, guru mengajarkan rasa bangga dan puas kepada siswa akan hasil yang dicapai sekalipun hasil itu masih kecil.

\section{Model PORPE}

PORPE (Predict. Organize, Rehearse, Practice, and Evaluate) merupakan strategi belajar yang dikembangkan oleh Simpson (1986) yang dirancang untuk membantu siswa dalam (1) merencanakan secara aktif, memonitor, dan mengevaluasi pembelajaran mereka mengenai isi bacaan; (2) mempelajari proses-proses yang berbelit-belit dalarn persiapan ujian esai; dan (3) menggunakan proses menulis untuk mempelajari isi bacaan. Tahapan model Porpe, sebagai berikut:

a. Predict dengan membuat prediksi berupa pertanyaan-pertanyaan esai. b. Organize dengan mengorganisasikan konsep dalarn bentuk mind mapping.

c. Rehearse dengan melatih kembali dengan cara mepresentasikan di depan.

d. Practice denga praktik yaitu menuliskan kembali dengan bahasanya sendiri.

e. Evaluate dengan cara siswa menjawab pertanyaan esai yang dibuat oleh guru.

\section{Model Membaca Berdasarkan Pola} Berpikir

Model membaca berdasarkan pola pikir menekankan pemahaman membaca yang didasarkan pada pola berpikir yang diterapkan dalam proses membaca. Beberapa model membaca berdasarkan pola pikir yang disebut dengan metafora membaca, yaitu bottom-up views, topdown views, dan interactive or integrative views (Hedgcock \& Ferris, 2009:17). Berikut penjelasan ketiga jenis model membaca berdasarkan pola berpikir tersebut.

\section{a. Model Bottom-Up}

Model bottom-up merupakan proses pemerolehan makna teks yang mengandalkan informasi tertulis dengan cara memahami kata per kata atau kalimat per kalimat.Dengan kata lain langkah-langkah dalam pembelajarannya dimulai dengan membaca bagian dari tataran kebahasaan yang paling rendah yaitu dari huruf sampai pada tatararan yang paling tinggi yaitu kalimat. Model ini cocok digunakan untuk pembelajaran membaca awal yang tidak membutuhkan pengetahuan awal atau sebelumnya dari pembaca. 
Beberapa langkah model pembelajaran bottom-up menurut Rahim (2011), sebagai berikut.

1) Dimulai dengan melihat hurufhuruf.

2) Huruf-huruf kemudian diidentifikasikan dan disuarakan.

3) Kenali kata-kata.

4) Kata-kata dilakukan pengelompokan ke dalam kelas gramatikal dan struktur kalimat.

5) Makna diterima dari kalimat.

6) Kemudian, makna dihubungkan dengan pemikiran.

b. Model Top-Down

Model membaca top-down merupakan proses kegiatan membaca dengan proses menafsirkan atau memaknai teks berdasarkan pengetahuan yang dimiliki pembaca (Mulyati, dalam Wartika, 2015:5). Model membaca top-down memiliki kelebihan, yaitu sederhana, praktis, dan inovatif. Model ini digunakan untuk meningkatkan kemampuan membaca dan motivasi dalam membaca.

Model pembelajaran membaca top-down menurut Tarigan (2013), dapat dilakukan dengan langkah-langkah sebagai berikut.

1) Mata langsung melihat pada teks.

2) Berpikir dan menduga tentang makna yang ada sesuai dengan pengatahuan dan pengalaman yang ada.

3) Melihat kalimat sebagai contoh keseluruhan untuk menemukan makna.
4) Proses mencari makna lebih jauh, pembaca melihat pada kata-kata.

5) Jika masih belum pasti, pemabaca melihat lagi pada huruf-huruf.

6) Kemudian, lakukanpencarian makna pada pemikiran yang sudah diperoleh dengan dihubungkan dengan pengetahuan.

\section{c. Model Interactive}

Model interactivehadir karena ketidakpuasan atas pemahaman bacaan yang ditawarkan oleh model bottom-up dan top-down. Sebenarnya model interactive memadukan konsep kerja dari model bottom-up dan top-down. Model interactivedapat diajarkan dengan membuat hubungan antara teks dengan teks, dan teks dengan dunia sebelum, selama, dan setelah membaca.

Dalam menerapkan model
membaca mempertimbangkan beberapa hal berikut: 1) model interactivememberikan keleluasaan bagi pembaca untuk medayagunakan kemampuan membaca, antara kemampuan bottom-up dan topdown secara baik; 2) model interactivetepat diterapkan dengan asumsi bahwa peserta didik telah memiliki sejumlah pengetahuan dan pengalaman; dan 3) latar belakang pengetahuan sangat membantu siswa dalam memahami makna teks. Hal ini sesuai denngan pendapat Moreillon (2007:25) bahwa dalam menilai dan membangun latar pengetahuan memberikan dukungan penting untuk memahami bacaan.

14. Model Pembelajaran Berbasis Genre 
Langkah umum model pembelajaran berbasis genre atau teks, terdiri atas empat tahap kegiatan, yaitu: pembangunankonteks, pemodelan teks, penyusunan teks bersama, dan penyusunan teks mandiri (Rose \& Martin,2012). Lebih lanjut model pembelajaran genre menurut Rose\&Martin (2012), dapat diterapkan dalam pembelajaran membaca dengan langkah-langkah berikut.

\section{a. Membangun Konteks}

Tahap ini merupakan langkahlangkah awal yang dilakukan guru bersama siswa untuk mengarahkan pemikiran ke dalam pokok persoalan yang akan dibahas pada materi bacaan dengan menghadirkan beberapa jenis teks. Teks yang diberikan bisa dalam bentuk teks otentik, teks adaptasi,teks modifikasi, teks buatan guru sendiri, atau teks yang diberikan oleh para ahli pendekatan genre-based yang relevan.

b. Menelaah Model/Dekonstruksi Teks

Tahap ini berisi tentang pembahasan teks yang diberikan sebagai model pembelajaran. Pembahasan diarahkan pada semua aspek kebahasaan yang membentuk teks itu secara keseluruhan. Pada tahap ini dikembangkan kemampuan berpikir kritis siswa melalui kegiatan membahas serta menjawab pertanyaanpertanyaan yang jawabannya tidak tertera dalam teks, seperti siapa penulisnya, kepada siapa pesan dalam teks ditujukan, di mana teks tersebut dapat ditemukan, dalam konteks apa teks itu dipakai, apakah setiap teks atau setiap pernyataan yang ada dalam teks relevan dengan kehidupan siswa, apakah setiap pernyataan yang ada dalam teks akan diterima oleh semua pembaca, apakah yang dikatakan dalam teks relevan dengan pengalaman siswa atau relevan dengan teks yang pernah dibaca sebelumnya oleh siswa terkait topik yang sama.

c. Latihan Terbimbing (Joint Construction)

Pada tahapan ini, siswa berlatih menggunakan semua hal yang telah dipahaminya pada tahap sebelumnya. Siswa melewati tahap brainstorming, drafting, revising, editing, proofreading, dan publishing.

d. Unjuk Kerja Mandiri (Independent Construction)

Pada tahapan ini, siswa diberi kesempatan untuk menulis secara mandiri, dengan bimbingan guru yang minimal, hanya kalau diperlukan. Setelah menulis teks secara mandiri, siswa juga dapat melakukan refleksi terkait apa yang telah ditulis atau yang dilakukan, atau apa yang telah dipelajari selama pembelajaran, dan saat membandingkan teks yang mereka tulis dengan teks yang ditulis oleh temannya. Siswa juga dapat menceritakan kembali apa yang telah ditulisnya di depan kelas.

\section{Model Content and Language Integrated Learning (CLIL)}

Model CLILmenurut Juan-Garau \& Salazar-Noguera (2015:255) merupakan model pembelajaran yang mengintegrasikan antara bahasa dan konten yang tujuannya memperpanjang pengalaman belajar bahasa dan motivasi dasar dalam berkomunikasi. Pembelajaran membaca dalam hal ini mencoba mengintegrasikan antara 
kegiatan berbahasa dengan misalnya dapat diintegrasikan dengan aspek kebahasaan, sastra, tema atau gagasan, dan keterampilan berbahasa dalam proses pembelajaran.

Model CLIL difokuskan pada pemahaman siswa terhadap bacaan setelah melalui proses membaca.Setelah itu, siswa mengaktualisasikan kemampuan membacanya melakukan unjuk kerja, baik secara lisan, maupun tulisan. Perlu diperhatikan dalam mengitegrasikan bahasa dan konten perlu memadukan pembelajaran bahasa dengan sub-sub disiplinnya atau bisa secara antardisiplin dengan cara mengintegrasikan pada tataran konsep, topik, dan proses.

\section{SIMPULAN}

Model pembelajaran dalam meningkatkan kemampuan membaca siswa yang sudah dan dapat diterapkan oleh para pengajar bahasa Indonesia yaitu model Anticipation Guide, model Model DRTA, Model SQ3R, model ECOLA, model Jigsaw Learning, model Index Card Match, model Card Sort, model $\mathrm{OH}$ RATS, Model Directed Inquiry Activity, model KWLA, model pembelajaran ARIAS, model PORPE, model membaca berdasarkan pola berpikir, model pembelajaran berbasis genre, dan Model CLIL. Beberapa model pembelajaran membaca tersebut bisa menjadi pilihan dalam menggunakan bahan ajar membaca yang dikembangkan dengan menyesuaikan dengan desain bahan ajar yang dikembangkan.

\section{DAFTAR PUSTAKA}

Harvey, S., \& Goudvis, A. (2013). Comprehension at the Core. The Reading Teacher, 66(6), 432-439. doi:10.1002/trtr.1145

Hedgcock, S. \& Feeris, D. R. (2009). Teaching Readers of English: Students, Texts, and Contexts. New York: Routledge.

Juan-Garau, M., \& Salazar-Noguera, J. (Eds.) (2015). Content-Based Language Learning in Multilingual Educational Environments. Netherlands: Springer.

Kubowitz, H. (2012). The Default Reader and a Model of Queer Reading and Writing Strategies or: Obituary for the Implied Reader. Literature, Bio-psychological Reality, and Focalization, 46(2). 202.

Mohamad, A. (2016). Kemampuan Membaca Bangsa Indonesia Urutan 60 Dunia. Online, diakses 1 September 2018. https://www.merdeka.com/dunia /kemampuan-membaca-bangsaindonesia-urutan-60-dunia.html

Moreillon, J. (2007). Collaborative Strategy for Teaching Reading Comprehension: Maximizing Your Imfact. Chicago: American Library Association.

Mullis, I.V.S., Martin, M.O., Foy, P., \& Drucker, K.T. (2012). PIRLS 2011 International Result ini Reading. Chelstnut Hill, MA: Boston College.

Ngalimun \& Alfulaila, N. (2014). Pembelajaran Keterampilan 
Berbahasa Indonesia. Yogyakarta: Aswaja Pressindo.

Noermanzah, N. (2015). Peran Dosen Bahasa dan Sastra Indonesia dalam Mempertahankan Bahasa Indonesia sebagai Alat Pemersatu Negara Kesatuan Republik Indonesia pada Era Globalisasi. In Prosiding Seminar Nasional Bulan Bahasa 2015. Unit Penerbitan FKIP Universitas Bengkulu, p. 274. http://repository.unib.ac.id/1113 3/

Rahim, F. (2011). Pengajaran Membaca di Sekolah Dasar. Jakarta: Bumi Aksara.

Rose, D., \& Martin, J.R. (2012). Learning to Write, Reading to Learn. London: Equinox.

Tarigan, H. G. (2013). Membaca sebagai Suatu Keterampilan Berbahasa. Bandung: Angkasa.
Tierney, R. J., Readence, J.E., \& Dishner, E.K. (1995). Reading Strategies and Practices: a Compendium. The United States of Amarica (USA): Allyn \& Bacon.

Tierney, Robert J., John E. Readence, \& Ernest K. Disher. (1990). Reading Strategies and Practice A Compendium. Boston: Allyn and Bacon.

Wartika, E. (2015). Penerapan Teknik Membaca Top Down untuk Meningkatkan Kemampuan Membaca Siswa Kelas IX di SMPN 2 Jatinangor. Jurnal Pendidikan Bahasa dan Sastra, 15(1), 5.

Wiesandenger, K. D. (2001). Strategies for Literacy Education. Columbus, Ohio: Merril Prentice Hall.

\section{NOTULEN SEMINAR}

1. Tanya Jawab Peserta

a. Ahlul dari FKIP Bahasa Indonesia UNIB mengajukan pertanyaan tentang model yang paling tepat digunakan disetiap jenjang pendidikan dan tanggapan pemakalah adalah dengan menggunakan model CLIL yang berbasis genre dengan menggunakna berbagai jenis teks yang dikaitkan dengan berbagai tekam yang kontekstual.

2. Saran Pembahas (Dr. Arono, M.Pd.)

a. Perlu perincian tentang sistematika fokus perkembangan dasar. 